\title{
15. HIGH-RESOLUTION PLEISTOCENE DIATOM BIOSTRATIGRAPHY AND PALEOCEANOGRAPHY OF SITE 919 FROM THE IRMINGER BASIN1
}

\author{
Nalân Koç² and Benjamin P. Flower
}

\begin{abstract}
Ocean Drilling Program Site 919 from the Irminger Basin provides one of the first opportunities to study high-resolution Pleistocene high-latitude North Atlantic diatom biostratigraphy and paleoceanography. Three Pleistocene diatom datum events are identified and tied directly to the stable oxygen isotope record of Site 919. These datum events are the (1) last occurrence of Thalassiosira nidulus at $0.310 \mathrm{Ma}$, (2) last occurrence of Proboscia curvirostris at $0.335 \mathrm{Ma}$, and (3) last occurrence of Neodenticula seminae at 0.817-0.895 Ma. Based on these datums, a Pleistocene diatom zonation for the high-latitude North Atlantic and the Nordic Seas is proposed using high-latitude cold species. The last occurrences of Thalassiosira nidulus and Proboscia curvirostris appear to be isochronous in the middle- to high-latitude North Pacific and the North Atlantic Oceans.

The diatom abundance and preservation record of Site 919 is used to infer polar front fluctuations during the last 1 m.y. Results indicate that during glacial Stages 2, 6, 10, 12, and 16 the polar front migrated eastward, covering Site 919 with sea-ice. Milder climate is indicated during glacial Stages 4, 8, 14, 18, and 20, as the polar front is interpreted to lie to the west of Site 919.
\end{abstract}

\section{INTRODUCTION}

The Cenozoic diatom biostratigraphy of the North Atlantic Ocean up to $60^{\circ} \mathrm{N}$ is well established (Baldauf, 1985, 1987). However, north of $60^{\circ} \mathrm{N}$, there is no well established diatom biostratigraphy partly due to the poor coring techniques employed during Deep Sea Drilling Project (DSDP) Leg 38 and Ocean Drilling Program (ODP) Leg 104, which resulted in poor recovery and poor magnetostratigraphy. These handicaps and the rare occurrence of many of the marker species limited the diatom biostratigraphic studies (Schrader and Fenner, 1976; Dzinoridze et al., 1978; Bodén, 1992). Recent drilling in the Nordic Seas (ODP Leg 151) provided excellent recovery and magnetostratigraphy, which led to the initial development of a detailed and reliable Cenozoic diatom biostratigraphy for the Nordic Seas (Koç and Scherer, in press).

The North Atlantic diatom zonation of Baldauf $(1985,1987)$ is not applicable in the Nordic Seas due to the endemic character of the species in this region. However, sites in the high-latitude North Atlantic (between $60^{\circ}-65^{\circ} \mathrm{N}$ ) south of Iceland might be a useful link to combine the Nordic Sea biostratigraphic scheme (Koç and Scherer, in press) with the North Atlantic zonation (Baldauf, 1985, 1987).

During ODP Leg 152, a transect of six sites was drilled on the Southeast Greenland Margin (Larsen, Saunders, Cliff, et al., 1994). The main drilling objective was deep sampling of the volcanic basement. To reach this objective, four sites (914-917) were drilled on the shelf and two sites (918-919) in the adjacent deep Irminger Ba$\sin$. Site 918 is located on the upper continental rise and is highly influenced by a submarine fan system that supplied coarse detritus to this area (see "Lithostratigraphy" section in Shipboard Scientific Party, 1994a.

Site $919\left(62^{\circ} 40.20^{\prime} \mathrm{N}, 37^{\circ} 27.611^{\prime} \mathrm{W}\right)$ is located in $2088.2 \mathrm{~m}$ of water on the continental rise of Southeast Greenland, within the western part of the Irminger Basin (Fig. 1). Two holes were drilled at Site 919: Hole 919A (10 cores) was cored continuously to a depth of 93.5

${ }^{1}$ Saunders, A.D., Larsen, H.C., and Wise, S.W., Jr. (Eds.), 1998. Proc. ODP, Sci. Results, 152: College Station, TX (Ocean Drilling Program).

${ }^{2}$ Department of Geology, University of Bergen, Allégt. 41, N-5007 Bergen, Norway.nalan.koc@geol.uib.no

${ }^{3}$ Earth Sciences Board, University of California, Santa Cruz, CA 95064, U.S.A. meters below seafloor (mbsf), and Hole 919B (eight cores) was cored and washed to a depth of $147 \mathrm{mbsf}$ in two parts. Recovery of sediment in the holes exceeds $100 \%$. The two holes, when combined, form a composite sequence $147 \mathrm{~m}$ thick. Due to the pelagic character, high rates of Pleistocene sedimentation, and the presence of wellpreserved diatoms at this site, Site 919 was chosen for detailed study to refine and increase the diatom biostratigraphic resolution of the Pleistocene middle- to high-latitude North Atlantic and Nordic Seas.

\section{METHODS}

No samples were processed on board for diatom biostratigraphic investigations. Later on shore, one sample from each core section $(1.5 \mathrm{~m})$ from Holes 919A and 919B was analyzed for its diatom content. Approximately 1-2 g of each dry sample was placed in a 250$\mathrm{mL}$ beaker, and 10 drops of $37 \% \mathrm{HCl}$ acid were added. After waiting for at least $15 \mathrm{~min}$ for the reaction to stop, 10 drops of $30 \%$ hydrogen peroxide were added. The sample was gently heated until the liquid became light yellow. The acidity of the sample was diluted by centrifuging it with distilled water until a $\mathrm{pH}$ of 7 was achieved. Quantitative slides of acid-cleaned material were examined at $400 \times$ for relative diatom abundance. Assessment of total diatom abundance was qualitative. Diatoms were recorded as abundant (A) if six or more specimens were present in one field of view at $400 \times$, common (C) if one to five specimens occurred in one field of view, few $(F)$ if one to four specimens occurred in five fields of view, and rare $(\mathrm{R})$ if one to 10 specimens occurred per horizontal traverse.

Qualitative estimates of abundance of individual taxa are based on the number of specimens observed per field of view at $400 \times$. Species were recorded as abundant (A) if two or more specimens were present in one field of view, common (C) if one to five specimens were observed per five fields of view, few $(F)$ if two to ten specimens were observed per horizontal traverse, rare $(R)$ if one specimen was observed per horizontal traverse, and trace $(\mathrm{T})$ if only fragments of the specimen were observed.

Diatom preservation was recorded as good $(\mathrm{G})$ when both finely silicified and heavily robust forms were present and no significant alteration of the frustules other than minor fragmentation was observed, moderate $(\mathrm{M})$ when the assemblage showed moderate breakage and slight dissolution, and poor $(\mathrm{P})$ when finely silicified forms 
Figure 1. Location of ODP Sites 919 and 918 in the western Irminger Basin. Plotted also are previous DSDP and ODP sites in the area. Position of the polar front is shown by dotted line.

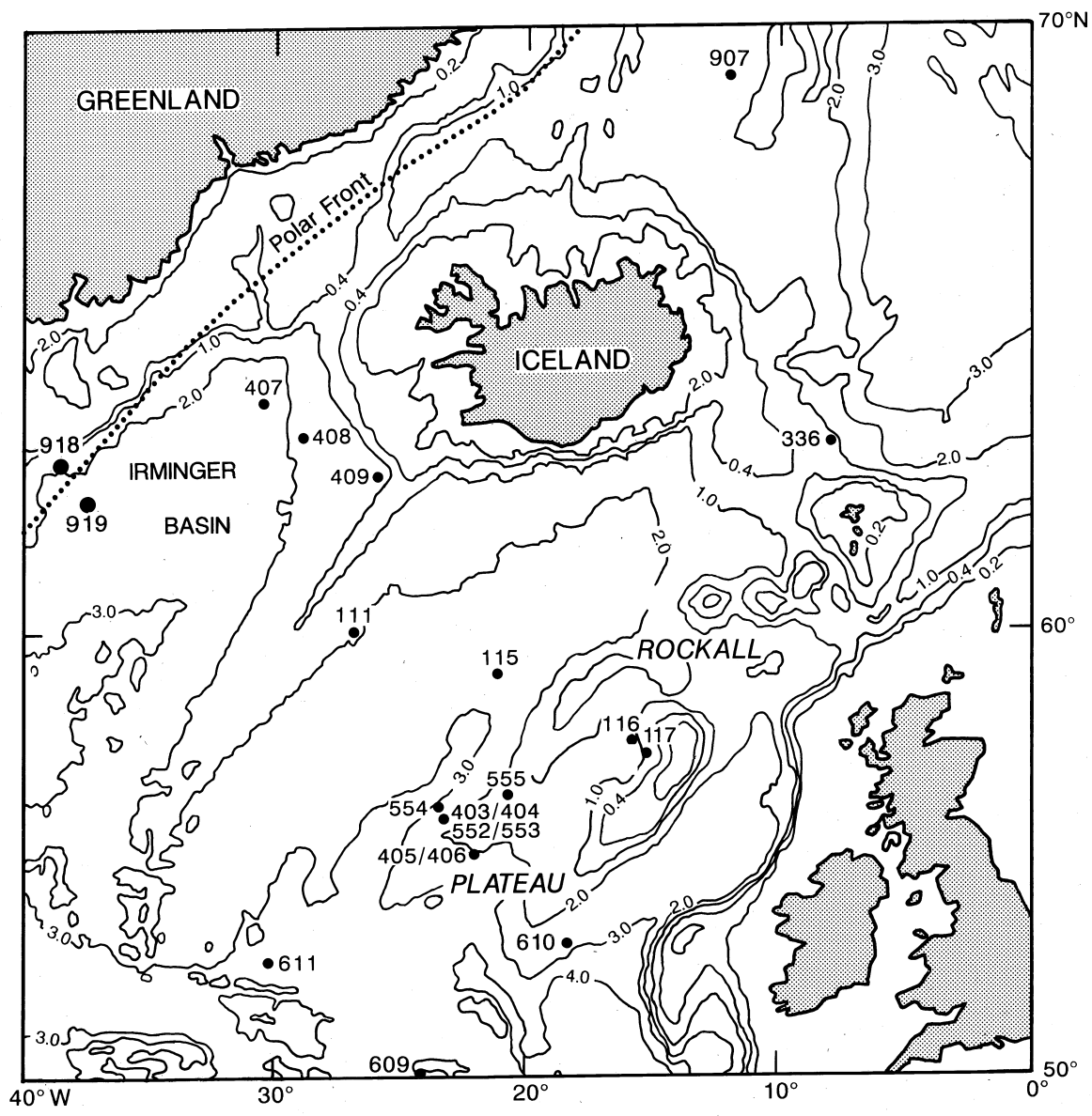

were rare or absent and the assemblage was dominated by robust forms and fragments.

\section{PLEISTOCENE DIATOM BIOSTRATIGRAPHY}

At present, the Irminger Basin is influenced by the southward surface flow of the cold and ice-laden East Greenland Current (EGC) in the west, and in the central parts by the confluence of these polar waters with the Atlantic waters of the Irminger Current creating modified North Atlantic waters (Fig. 2). Site 919 in the western Irminger Basin today is primarily under the influence of the EGC. The Pleistocene diatom species observed in sediment recovered from Site 919 primarily consist of modern polar and arctic species (Koç Karpuz and Schrader, 1990; Koç, unpubl. data) (Plate 1). These include Actinocyclus curvatulus, Thalassiosira gravida spore and vegetative cells, Thalassiosira trifulta, Thalassiothrix longissima, and the warmwater species Thalassiosira oestrupii (Table 1).

Three biostratigraphic events are observed in Holes 919A and 919B: the last occurrence (LO) of Thalassiosira nidulus, the LO of Proboscia curvirostris, and the LO of Neodenticula seminae (Fig. 3; Plate 2). The LO of Thalassiosira nidulus is observed in Sample 152919A-5H-4, 40-41 cm (41.4 mbsf). The LO of Proboscia curvirostris is observed in Sample 152-919A-5H-7, 35-36 cm (45.85 mbsf). The LO of Neodenticula seminae is observed in Sample 152-919B7H-7, 40-41 cm (137.4 mbsf) (Table 1).

\section{Correlation to the Isotope Record}

Precise dating of these biostratigraphic events is achieved by correlating the events to the oxygen isotope record of Site 919 (Flower, this volume). The LO of $T$. nidulus and the LO of $P$. curvirostris occur within isotope Stage 9 (Fig. 3). Interpolation of age using the stage boundaries gives an age of $0.309 \mathrm{Ma}$ for the LO of T. nidulus and an age of $0.335 \mathrm{Ma}$ for the LO of P. curvirostris. The LO of $N$. seminae occurs within isotope Stage 22 ; however, because there is a barren interval above this event, the age is interpolated to be between 0.817 and $0.895 \mathrm{Ma}$. The LO of T. nidulus is dated between 0.280 and $0.390 \mathrm{Ma}$ in the Northwest Pacific, showing a possible diachrony from high to low latitudes (Koizumi and Tanimura, 1985). The datum of $0.309 \mathrm{Ma}$ for the LO of T. nidulus from Site 919 falls closer to the younger datum from the North Pacific. It is possible to conclude that this event is synchronous between the middle to high latitudes of both oceans.

The LO of $P$. curvirostris is dated at $0.300-0.350 \mathrm{Ma}$ in the middle- to high-latitude North Pacific (Koizumi and Tanimura, 1985; Koizumi, 1986). Baldauf (1985) correlated the LO of P. curvirostris datum at Site 552 in the North Atlantic to isotope Stage 10 and assigned an approximate age of $0.360 \mathrm{Ma}$. However, this must be taken as a minimum age because it is based on observations from a single sample. At Site 646, from the southern Labrador Sea, the LO of $P$. curvirostris is observed in Sample 105-646A-3H-1, 128-130 cm, and estimated to be $0.27 \mathrm{Ma}$ based on a linear interpolation between the core top and the Brunhes/Matuyama boundary (Monjanel and Baldauf, 1989). The overlap in age observed between the North Atlantic and the North Pacific suggests synchroneity between these two oceans for this event. Baldauf $(1985,1987)$ recorded the occurrence of $P$. curvirostris from Sites 552, 606, 607, 609, and 611 in the North Atlantic. Proboscia curvirostris is also recorded from the Nordic Seas Sites 907 (Koç and Scherer, in press) and 986 (Jansen and Raymo, in press). This suggests that $P$. curvirostris has a distribution that stretches from $40^{\circ} \mathrm{N}$ in the North Atlantic to the high-latitude Nordic 


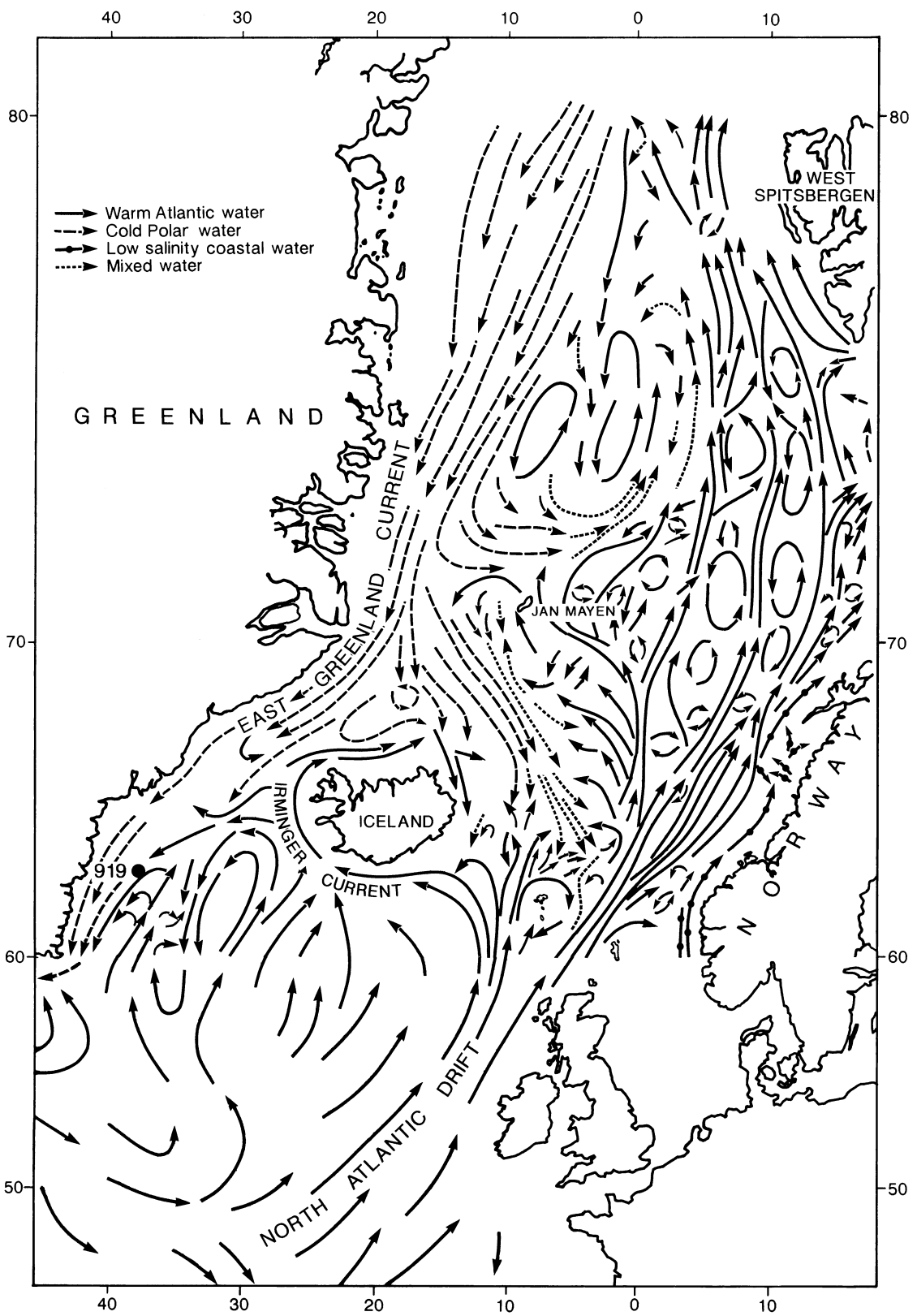

Figure 2. Modern surface currents in the Nordic Seas and the North Atlantic from Alekseev and Istochin (1956). Also plotted is the position of ODP Site 919 in the western Irminger Basin.
Seas, and therefore may be a useful biostratigraphic datum. It also has a middle- to high-latitude distribution in the North Pacific, which makes correlations between the high-latitude North Atlantic and the North Pacific possible.

Denticulopsis seminae belongs to the modern assemblage of the middle- to high-latitude North Pacific (Barron, 1981). However, it went extinct in the North Atlantic during the late Quaternary (Baldauf, 1986). Baldauf (1986) found the LO of Denticulopsis seminae to be diachronous between Site 607 (about $0.8 \mathrm{Ma}$ ) and Sites 609 and 611 (about $0.7 \mathrm{Ma}$ ). Since the age from Site 919 (0.817-0.895 $\mathrm{Ma}$ ) is closer to the one from Site 607, which is the southernmost site, it seems that the calculated ages from Sites 609 and 611 are too young for this event. Monjanel and Baldauf (1989) recorded the LO of $D$. seminae at Site 646 from the southern Labrador Sea in Sample 105646A-7H-5, 120-122 cm. We have correlated this sample to the oxygen isotope record of Hole 646A (Aksu et al., 1989). It plots near the midpoint of isotope Stage 21, thereby giving an age of about 0.818 $\mathrm{Ma}$. This age correlates well with the age of $0.817-0.895 \mathrm{Ma}$ from Site 919.

\section{Zonation}

The diatom zones defined for the North Atlantic (Baldauf, 1985, 1987) are based partially on eastern equatorial North Pacific diatom zonation schemes (Barron, 1981; Baldauf, 1986). Thus, most of the zones are defined by warm-temperate species. The youngest North Atlantic diatom zone, the Pseudoeunotia doliolus Zone (Baldauf, 1985, 1987), was defined by Burckle (1977) from the equatorial Pacific as the interval containing Pseudoeunotia doliolus that ranges stratigraphically above the LO of Nitzschia reinholdii $(0.440 \mathrm{Ma})$ to the present. This zone also was recognized in DSDP Leg 81 and 94 sites from the middle- and high-latitude North Atlantic (Baldauf, 1985, 1987). However, it was impossible to recognize this zone both at Sites 919 and 907 due to the absence of Nitzschia reinholdii and the very sparse occurrence of Pseudoeunotia doliolus.

A Pleistocene diatom zonation scheme is proposed below using high-latitude cold-water species for the high-latitude North Atlantic and the Nordic Seas (modified from Koç and Scherer, in press) (Fig. 4). 


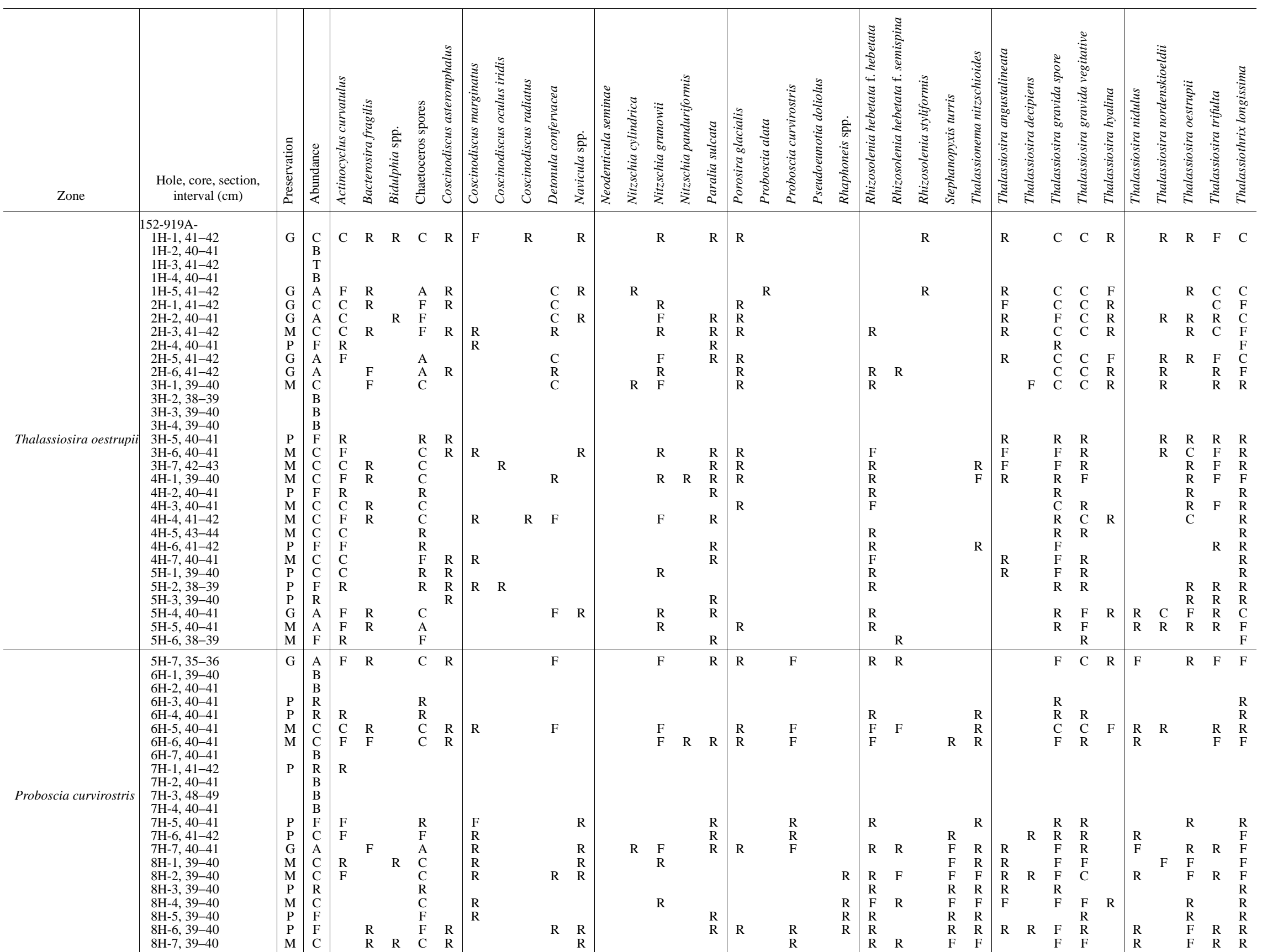


Table 1 (continued).

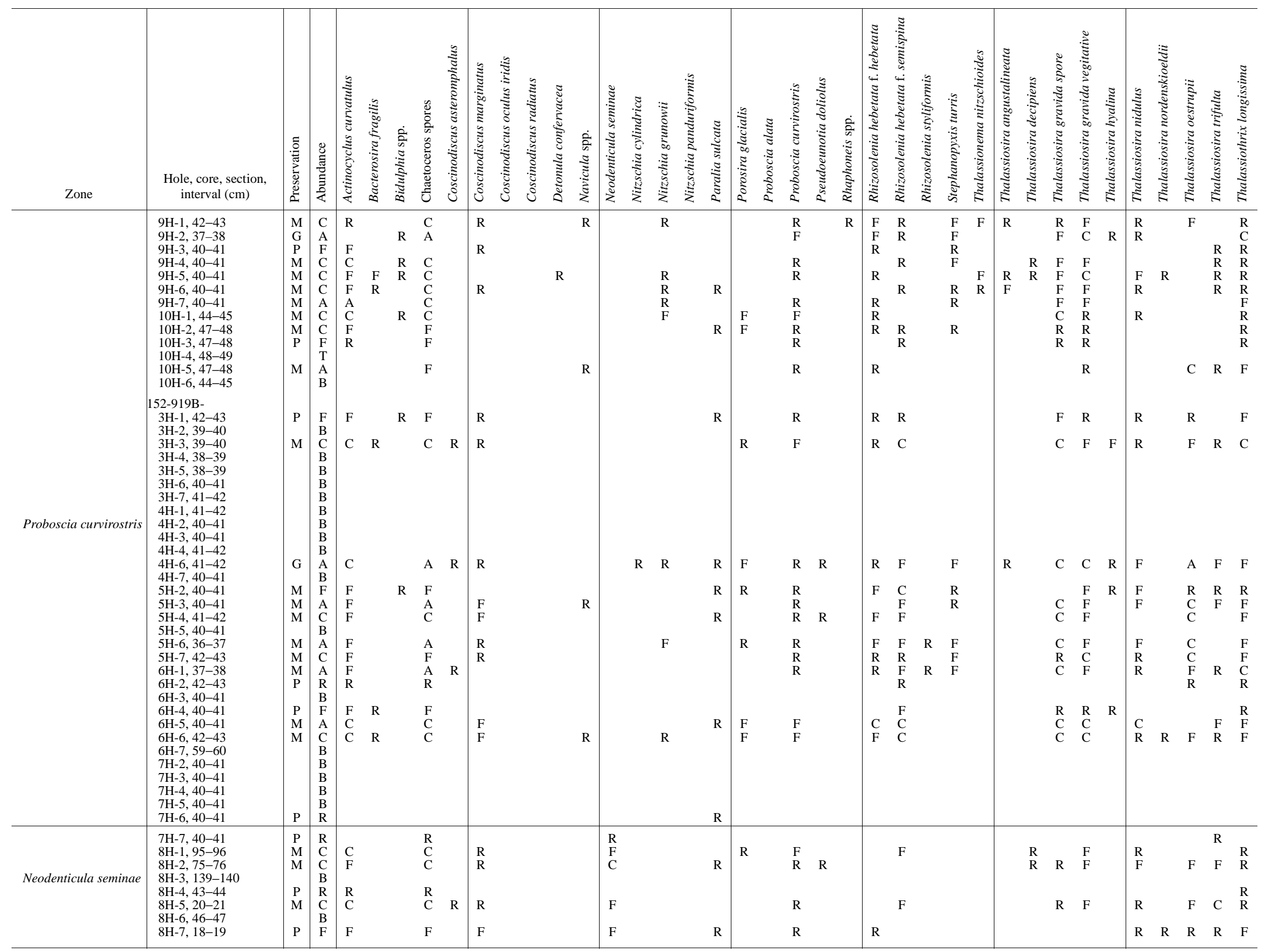


Diatom Abundances $\quad \partial^{18} \mathrm{O}(\% \circ \mathrm{PDB})$

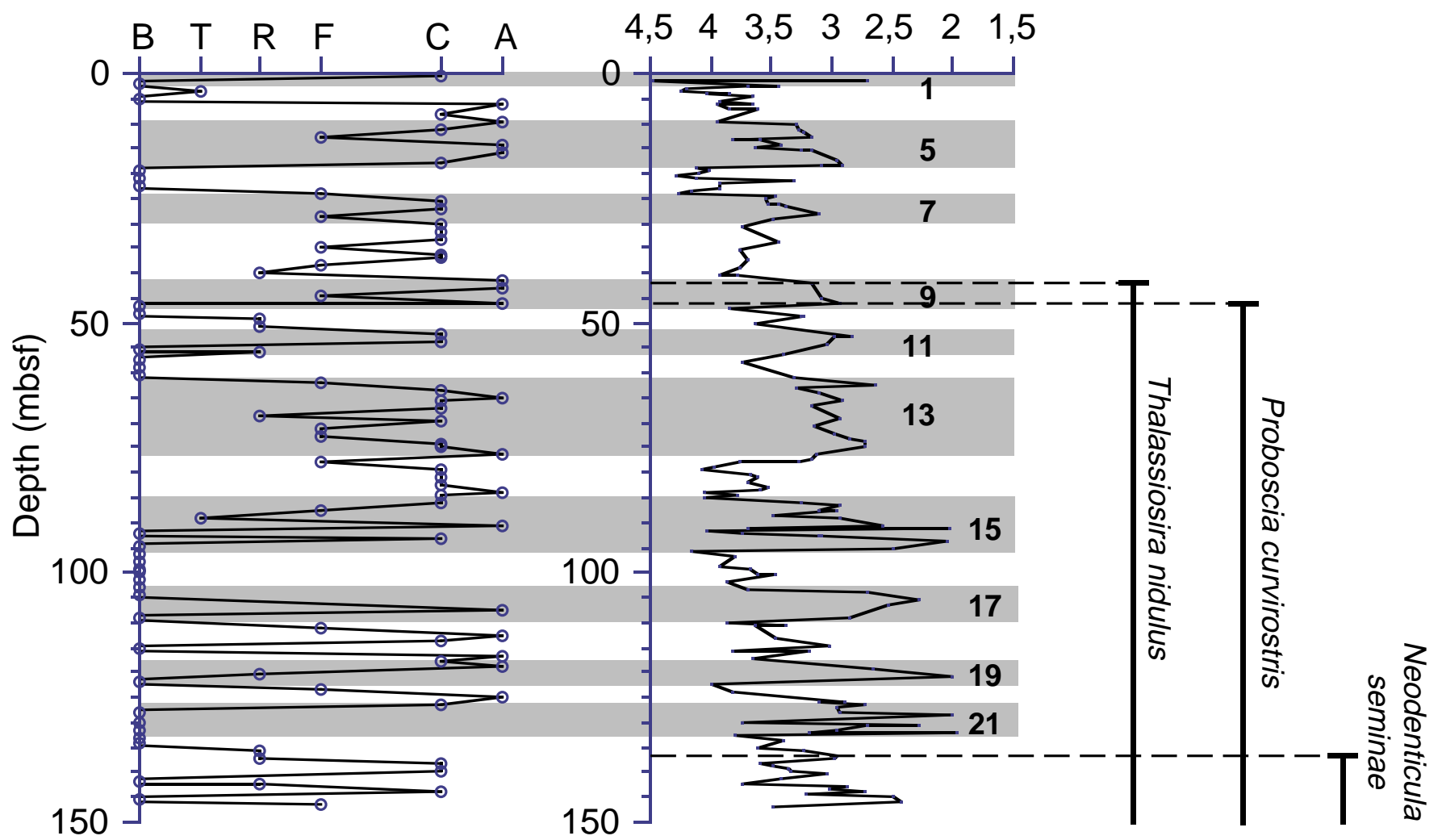

Figure 3. Site 919 relative diatom abundances $(\mathrm{B}=$ barren, $\mathrm{T}=$ trace, $\mathrm{R}=$ rare, $\mathrm{F}=$ few, $\mathrm{C}=$ common, and $\mathrm{A}=$ abundant $)$ plotted with the $\delta^{18} \mathrm{O}$ record against composite depth. Interglacial stages are shaded and numbered. Diatom biostratigraphic events and their ranges are indicated and correlated to the $\delta^{18} \mathrm{O}$ record.

\section{Thalassiosira oestrupii Zone}

Authors. Koç and Scherer (in press).

Definition. The interval from the LO of Proboscia curvirostris to the present.

Remarks. Koç and Scherer (in press) could not date the base of this zone precisely because the $\mathrm{LO}$ of $P$. curvirostris occurred within an interval that was mostly barren.

Correlation. This zone correlates to the Neodenticula seminae (NPD12) Zone (Donahue, 1970) of the North Pacific, which also uses the LO of P. curvirostris to define its base (Fig. 5).

Age. Quaternary, 0.335-0 Ma.

\section{Proboscia curvirostris Zone}

Author. Koç (this study).

Definition. The top of the zone is defined by the LO of P. curvirostris and the base by the LO of Neodenticula seminae.

Remarks. The base of this zone is modified from its original description by Koç and Scherer (in press) as the interval from the LO of Thalassiothrix miocenica to the LO of $P$. curvirostris. This interval included an extended, mostly barren section at its original site of description (Site 907). The LO of Thalassiosira nidulus occurs right above the top of this zone (Fig. 4).

Correlation. This zone correlates to the Rhizosolenia curvirostris (synonym for Proboscia curvirostris) Zone of the North Pacific (Donahue, 1970) (Fig. 5).

Age. Quaternary, $0.817-0.894$ to $0.335 \mathrm{Ma}$.

\section{Neodenticula seminae Zone}

Author. Koç (this study).

Definition. The top of the zone is defined by the LO of Neodenticula seminae and the base by the LO of Thalassiothrix miocenica.

Remarks. The base of this zone is not observed at Site 919.
Correlation. This zone encompasses the North Pacific zones from the Actinocyclus oculatus Zone to the Neodenticula koizumii-N. kamtschatica Zones (Koizumi, 1973).

Age. Late Pliocene through late Pleistocene, 3.328 to $0.894-0.817$ Ma.

\section{DIATOM ABUNDANCES: PALEOCEANOGRAPHIC IMPLICATIONS}

Site 919 lies in a position to monitor fluctuations in the polar front (Fig. 1). Diatom abundance and preservation at this site fluctuate in response to changing oceanographic conditions affecting diatom productivity. Correlating variation in diatom abundance to the oxygen isotope record of Site 919 shows that generally the interglacials are related to high diatom productivity (common to abundant diatoms) (Fig. 3), whereas glacial Stages 2, 6, 10, 12, and 16 are barren of diatoms. However, during glacial Stages 4, 8, 14, 18, and 20, there was significant diatom production.

Lack of surface-water productivity during Stages 2, 6, 10, 12, and 16 indicates that these were the intervals during which the polar front migrated farthest east, thereby covering Site 919 with sea-ice. Considering the proximity of the sea-ice margin to the area at present, it is very probable that these diatom-barren glacial intervals reflect periods when the site was under heavy sea-ice cover. We can, thus, conclude that these were the severest glacial periods of the last 1 m.y.

The presence of significant diatom production during glacial Stages 4,8,14, 18, and 20 indicates open marine conditions over Site 919 during these times. Benthic oxygen isotope records show light isotopic excursions, indicating some warming during these glacials (Shackleton et al., 1990). Planktonic oxygen isotope records from the Nordic Seas also record these light isotopic excursions (Fronval and Jansen, in press). Results indicate that during the glacial Stages 4, 8 , 


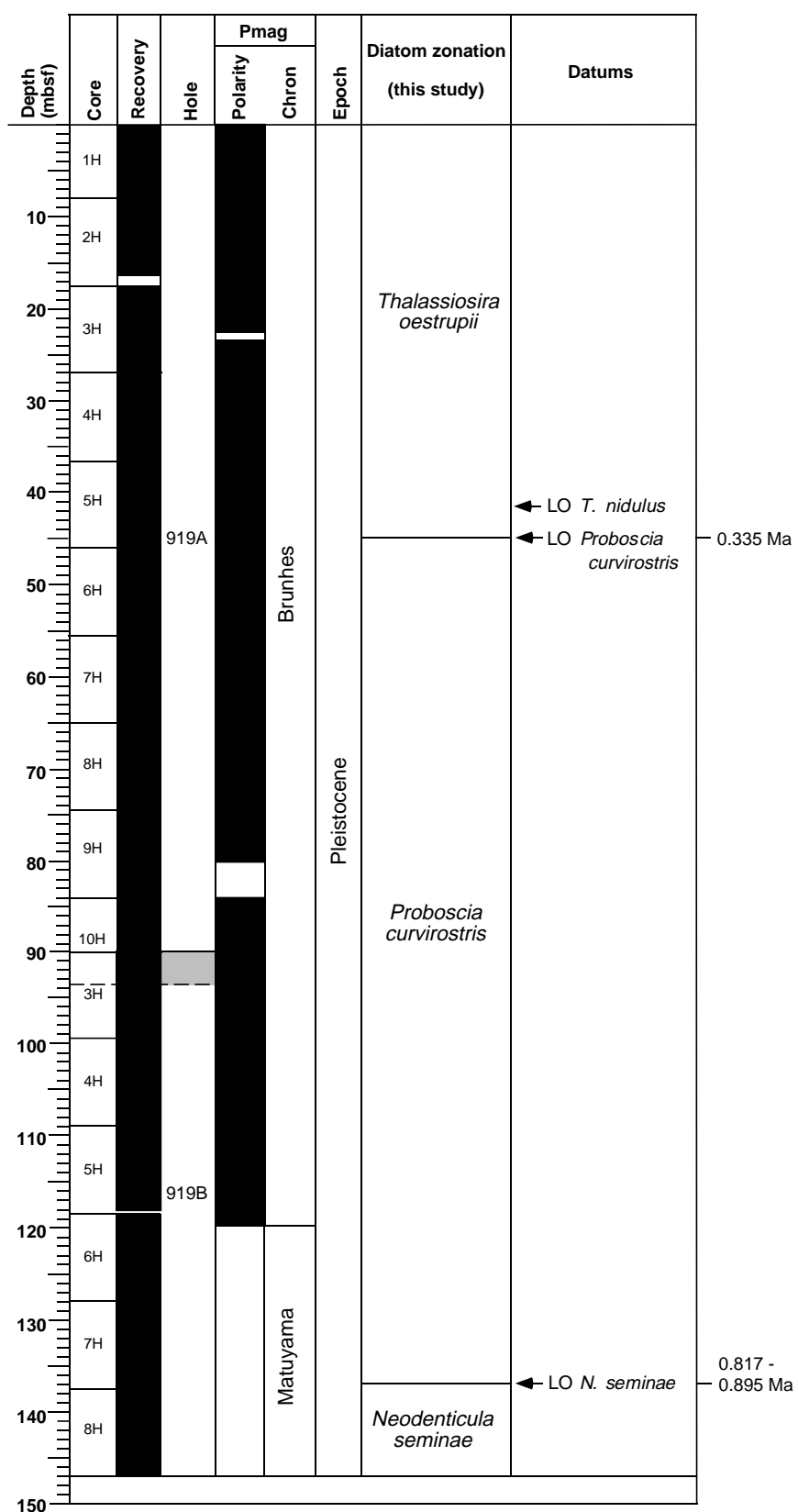

Figure 4. Stratigraphic position of cores, recovery, paleomagnetic stratigraphy, epoch, diatom zonation, and datums. The magnetostratigraphy shown is that of Shipboard Scientific Party (1994b). LO = last occurrence.

14,18 , and 20, the polar front was positioned west of Site 919, and that these glacial periods were milder than Stages 2, 6, 10, 12, and 16.

\section{CONCLUSIONS}

Diatom investigations of Site 919 have refined and increased the Pleistocene diatom biostratigraphic resolution of the high-latitude North Atlantic considerably.

Three Pleistocene diatom datum events are identified and tied directly to the stable oxygen isotope record of Site 919 . These datum events are (1) the LO of Thalassiosira nidulus at $0.310 \mathrm{Ma}$, (2) the LO of Proboscia curvirostris at $0.335 \mathrm{Ma}$, and (3) the LO of Neodenticula seminae around $0.817-0.895 \mathrm{Ma}$.

Three diatom zones, based on these datums, are proposed for the Pleistocene in the high-latitude North Atlantic and the Nordic Seas.
The record of diatom abundance and preservation at Site 919 indicates that during glacial Stages 2, 6, 10,12, and 16, the polar front migrated eastward covering Site 919 with sea-ice. During glacial Stages 4, 8, 14, 18, and 20, the polar front was positioned west of Site 919 , indicating that these glacial periods were milder than Stages 2, $6,10,12$, and 16 .

\section{ACKNOWLEDGMENTS}

We are grateful to David M. Harwood, Naja Mikkelsen, and Sherwood W. Wise, Jr., for their constructive and careful reviews. We thank Hans Christian Larsen and Andrew D. Saunders for the opportunity to participate in Leg 152 scientific work. We thank O. Tumyr for his assistance with the SEM pictures. This study is supported by grants from the Norwegian Research Foundation to N. Koç.

\section{REFERENCES}

Akiba, F., 1986. Middle Miocene to Quaternary diatom biostratigraphy in the Nankai trough and Japan trench, and modified lower Miocene through Quaternary diatom zones for middle-to-high latitudes of the North Pacific. In Kagami, H., Karig, D.E., Coulbourn, W.T., et al., Init. Repts. DSDP, 87: Washington (U.S. Govt. Printing Office), 393-481.

Akiba, F., and Yanagisawa, Y., 1986. Taxonomy, morphology and phylogeny of the Neogene diatom zonal marker species in the middle-to-high latitudes of the North Pacific. In Kagami, H., Karig, D.E., Coulbourn, W.T., et al., Init. Repts. DSDP, 87: Washington (U.S. Govt. Printing Office), 483-554.

Aksu, A.E., de Vernal, A., and Mudie, P.J., 1989. High-resolution foraminifer, palynologic, and stable isotopic records of upper Pleistocene sediments from the Labrador Sea: paleoclimatic and paleoceanographic trends. In Srivastava, S.P., Arthur, M.A., Clement, B., et al., Proc. ODP, Sci. Results, 105: College Station, TX (Ocean Drilling Program), 617652.

Alekseev, A.P., and Istochin, B. V., 1956. Chart of constant current in the Norwegian and Greenland Seas. Trans. Knipovich Polar Sci. Inst., 9:6268.

Baldauf, J.G., 1985. Cenozoic diatom biostratigraphy and paleoceanography of the Rockall Plateau Region, North Atlantic, Deep Sea Drilling Project Leg 81. In Roberts, D.G., Schnitker, D., et al., Init. Repts. DSDP, 81: Washington (U.S. Govt. Printing Office), 439-478.

1986. Diatom biostratigraphic and paleoceanographic interpretations for the middle and high latitude North Atlantic Ocean. In Summerhayes, C.P., and Shackleton, N.J. (Eds.), North Atlantic Paleoceanography. Geol. Soc. Spec. Publ. London, 21:243-252.

, 1987. Diatom biostratigraphy of the middle- and high-latitude North Atlantic Ocean, Deep Sea Drilling Project Leg 94. In Ruddiman, W.F., Kidd, R.B., Thomas, E., et al., Init. Repts. DSDP, 94 (Pt. 2): Washington (U.S. Govt. Printing Office), 729-762.

Barron, J.A., 1981. Late Cenozoic diatom biostratigraphy and paleoceanography of the middle-latitude eastern North Pacific, Deep Sea Drilling Project Leg 63. In Yeats, R.S., Haq, B.U., et al., Init. Repts. DSDP, 63: Washington (U.S. Govt. Printing Office), 507-538.

Bodén, P., 1992. Quantitative biostratigraphy of Neogene diatoms from the Norwegian Sea, North Atlantic and North Pacific. Stockholm Contrib. Geol., 42:124-202.

Brightwell, T., 1858. Remarks on the genus Rhizosolenia of Ehrenberg. Q. J. Microsc. Sci., 6:1-93.

Burckle, L.H., 1977. Pliocene and Pleistocene diatom datum levels from the equatorial Pacific. Quat. Res., 7:330-340.

Cleve, P.T., 1873. Examination of diatoms found on the surface of the Sea of Java. Bih. Sven. Vetensk.-Akad. Handl., 11:113.

1896. Diatoms from Baffin Bay and Davis Strait. Bihang till Kongl. Sven. Vetensk._Akad. Handl., Afd. 3, 22:1-22.

Cleve, P.T., and Grunow, A., 1880. Beiträge zur Kenntnis der arktischen Diatomeen. Konigl. Svensk. Vetensk. Akad. Handl., 17:3-122.

Donahue, J.G., 1970. Pleistocene diatoms as climatic indicators in North Pacific sediments. In Hays, J.D. (Ed.), Geological Investigations of the North Pacific. Mem.-Geol. Soc. Am., 126:121-138.

Dzinoridze, R.N., Jousé, A.P., Koroleva-Golikova, G.S., Kozlova, G.E., Nagaeva, G.S., Petrushevskaya, M.G., and Strelnikova, N.I., 1978. Diatom and radiolarian Cenozoic stratigraphy, Norwegian Basin; DSDP Leg 38. In Talwani, M., Udintsev, G., et al., Init. Repts. DSDP, 38, 39, 40, 41 (Suppl.): Washington (U.S. Govt. Printing Office), 289-427. 
Ehrenberg, C.G., 1839. Über noch jetz zahlreich lebende Tierarten der Kreidebildung und den Organismus der Polythalamien. Abh. K. Akad. Wiss. Berlin, 81-174.

_ 1841 . Uber Verbreitung und Einfluss des mikroskopischen Lebens in Süd- und Nordamerika. Abh. K. Akad. Berlin, 139-144.

Fenner, J., 1978. Cenozoic diatom biostratigraphy of the equatorial and southern Atlantic Ocean. In Perch-Nielsen, K., Supko, P.R., et al., Init. Repts. DSDP, 39 (Suppl., Pt. 2): Washington (U.S. Govt. Printing Office), 491-624.

Fronval, T., and Jansen, E., in press. Late Neogene paleoclimates and paleoceanography in the Iceland-Norwegian Sea: evidence from the Iceland and Vøring Plateaus. In Thiede, J., Myhre, A.M., Firth, J.V., Johnson, G.L., and Ruddiman, W.F. (Eds.), Proc. ODP, Sci. Results, 151: College Station, TX (Ocean Drilling Program)

Fryxell, G.A., and Hasle, G.R., 1977. The genus Thalassiosira: species with a modified ring of central strutted process. Nova Hedwigia (Beih.), 54:6798.

Fryxell, G.A., and Hasle, G.R., 1979. The genus Thalassiosira: T.trifuta sp. nova and other species with tricolumnar supports on strutted processes. Nova Hedwigia Beih., 64:13-31.

Gran, H.H., 1900. Bemerkungen über einige Planktondiatomeen. Nyt. Mag. Naturv. (Kristiania), 38:103-126.

, 1904. Die Diatomeen der Arktischen Meere, I. Teil: Die Diatomeen des Planktons. Fauna Arct., 3:509-554

Gregory, W., 1857. On new forms of marine Diatomaceae found in the Firth of Clyde and in Loch Fyne. Trans. R. Soc. Edinburgh, 21:473-542.

Hasle, G.R., 1960. Phytoplankton and ciliate species from the tropical Pacific. Skr. Nor. Vidensk.-Akad. Kl.1: Mat.-Naturvedensk. Kl., 2:150 .

, 1965. Nitzschia and Fragilariopsis species in the light and electron microscopes. III. The genus Fragilariopsis. Skr. Nor. Vidensk.-Akad. Kl. 1: Mat.-Naturv. Kl., 21:5-49.

, 1973. Some marine plankton genera of the diatom family Thalassiosiraceae. Nova Hedwigia Beih., 45:1-49.

Hasle, G.R., and Heimdal, B.R., 1968. Morphology and distribution of the marine centric diatom Thalassiosira antarctica Comber. J. R. Microsc. Soc. London, 88:357-369.

Hasle, G.R., and Semina, H.J., 1987. The marine planktonic diatoms Thalassiothrix longissima and Thalassiothrix antarctica with comments on Thalassionema spp. and Synedra reinboldii. Diatom Res., 2:175-192.

Hustedt, F., 1927-1966. Die Kieselalgen Deutschlands, Osterreichs und der Schweiz, mit Berücksichtigung der übrigen Länder Europas sowie der angrenzenden Meeresgebiete. In Rabenhorst, L. (Ed.), KryptogamenFlora von Deutschland. Oesterreich und der Schweiz: Leipzig (Akademische Verlagsgesellschaft), Teil I, Sect. 1-4, pp. 1-920, 1927-1930; Teil II, Sect. 1-5, pp. 1-845, 1931-1959; Teil III, Sect. 1-3, pp. 1-816, 1961-1966.

Jansen, E., Raymo, M., et al., in press. Proc. ODP, Init. Repts., 162: College Station, TX (Ocean Drilling Program).

Jordan, R.W., and Priddle, J., 1991. Fossil members of the diatom genus Proboscia. Diatom Res., 6:55-61.

Jørgensen, E.G., 1905. The protist plankton and the diatoms in bottom samples. In Nordgaard, O. (Ed.), Hydrological and Biological Investigations in Norwegian Fjords: Bergen (John Grieg).

Jousé, A.P., 1959. Species novae bacillariophytorum in sedimentis fundi oceani Pacifici et Mario Ochctensis inventae. Novitates Systematicae Plantarum non Vascularum, Akad. Sci. SSSR, Inst. Botan. Nom. V. L. Komarovii, 3:12-21.

1961. Diatoms and their roles in indicating the history of oceans. Akad. Nauk. SSSR, Izv. Ser. Geogr., 2:13-20.

_ 1962. Stratigraphic and paleogeographic investigations in the northwest part of the Pacific ocean. Akad. Nauk SSR Oceanol. Inst., Moscow.

Koç, N., and Scherer, R., in press. Neogene diatom biostratigraphy of the Iceland Sea Site 907. In Thiede, J., Myhre, A.M., Firth, J.V., Johnson, G.L., and Ruddiman, W.F. (Eds.), Proc. ODP, Sci. Results, 151: College Station, TX (Ocean Drilling Program).

Koç Karpuz, N., and Schrader, H., 1990. Surface sediment diatom distribution and Holocene paleotemperature variations in the Greenland, Iceland and Norwegian Sea. Paleoceanography, 5:557-580.

Koizumi, I., 1973. The late Cenozoic diatoms of Sites 183-193, Leg 19 Deep Sea Drilling Project. In Creager, J.S., Scholl, D.W., et al., Init. Repts. DSDP, 19: Washington (U.S. Govt. Printing Office), 805-855.

, 1986. Pliocene and Pleistocene diatom datum levels related with paleoceanography in the Northwest Pacific. Mar. Micropaleontol., 10:309-325.
Koizumi, I., and Tanimura, Y., 1985. Neogene diatom biostratigraphy of the middle latitude western North Pacific, Deep Sea Drilling Project Leg 86. In Heath, G.R., Burckle, L.H., et al., Init. Repts. DSDP, 86: Washington (U.S. Govt. Printing Office), 269-300.

Larsen, H.C., Saunders, A.D., Clift, P.D., et al., 1994. Proc. ODP, Init. Repts., 152: College Station, TX (Ocean Drilling Program).

Monjanel, A.-L., and Baldauf, J.G., 1989. Miocene to Holocene diatom biostratigraphy from Baffin Bay and Labrador Sea, Ocean Drilling Program Sites 645-646. In Srivastava, S.P., Arthur, M.A., Clement, B., et al., Proc. ODP, Sci. Results, 105: College Station, TX (Ocean Drilling Program), 305-322.

Pritchard, A., 1861. History of Infusoria, Living and Fossil (4th ed., rev. and enl. by Arlidge, J.T., Archer, W., Ralfs, J., Williamson, W.C., and the author): London (Whittiker and Co.).

Proshkina-Lavrenko, A.J., 1949. Diatomovyj Analiz: centrales mediales. Bot. Inst. Akad. Nauk SSSR, 2:1-238.

Sancetta, C., 1982. Distribution of diatom species in surface sediments of the Bering and Okhotsk Seas. Micropaleontology, 28:221-257.

Schmidt, A., et al., 1874-1959. Atlas der Diatomaceenkunde:Leipzig (R. Reisland). [Begun by Schmidt, A., continued by Schmidt, M., Fricke, F., Herden, H., Muller, O., and Hustedt, F.]

Schrader, H.-J., 1974. Revised diatom stratigraphy of the Experimental Mohole Drilling, Guadalupe Site. Proc. Calif. Acad. Sci., 39:517-562.

Schrader, H.-J., and Fenner, J., 1976. Norwegian Sea Cenozoic diatom biostratigraphy and taxonomy. In Talwani, M., Udintsev, G., et al., Init. Repts. DSDP, 38: Washington (U.S. Govt. Printing Office), 921-1099.

Shackleton, N.J., Berger, A., and Peltier, W.A., 1990. An alternative astronomical calibration of the lower Pleistocene timescale based on ODP Site 677. Trans. R. Soc. Edinburgh: Earth Sci., 81:251-261.

Shipboard Scientific Party, 1994a. Site 918. In Larsen, H.C., Saunders, A.D., Clift, P.D., et al., Proc. ODP, Init. Repts., 152: College Station, TX (Ocean Drilling Program), 177-256.

1994b. Site 919. In Larsen, H.C., Saunders, A.D., Clift, P.D., et al., Proc. ODP, Init. Repts., 152: College Station, TX (Ocean Drilling Program), 257-277.

Simonsen, R., 1979. The diatom system: ideas on phylogeny. Bacillaria, 2:9-71

Simonsen, R., and Kanaya, T., 1961. Notes on the marine species of the diatom genus Denticula Kütz. Int. Rev. Gesamten Hydrobiol., 46:498-513.

Sundström, B.G., 1986. The marine diatom genus Rhizosolenia: a new approach to the taxonomy [Ph.D. dissert.]. Lund Univ., Sweden.

Van Heurck, H., 1880-1885. Synopsis des Diatomées de Belgique: Antwerp (privately published).

Van Heurck, H., 1896. A treatise on the Diatomaceae (trans. W.E. Baxter): London (W. Wesley and Sons).

Date of initial receipt: 8 November 1995

Date of acceptance: 12 June 1996

Ms 152SR-218

\section{APPENDIX}

List of Flora

Actinocyclus curvatulus Janisch, 1878, in Schmidt et al. (1874-1959), pl. 57, fig. 31; Hustedt, 1958, pp. 129-130, pl. 8, fig. 81.

Bacterosira fragilis Gran, 1900, p. 114; Jousé, 1962, fig. 2, no. 15; Sancetta, 1982 , p. 227 , pl. 2 , figs. $1-4$

Coscinodiscus asteromphalus Ehrenberg, 1844, in Hustedt, 1930, pp. 452454 , fig. 250.

Coscinodiscus marginatus Ehrenberg, 1841, p. 142; Hustedt, 1930, p. 416, fig. 223.

Coscinodiscus oculus iridis Ehrenberg, 1839, p. 147; Hustedt, 1930, pp. 454459 , fig. 252

Coscinodiscus radiatus Ehrenberg, 1839, p. 148, pl. 3, figs. 1a-c; Hustedt, 1930, p. 420, fig. 255.

Detonula confervacea (Cleve) Gran. Hasle, 1973, pp. 1-49.

Neodenticula seminae (Simonsen and Kanaya) Akiba and Yanagisawa, 1986, p. 491, 492, pl. 24, figs. 1-11, pl. 26, figs. 1-10. Synonym: Denticula seminae Simonsen and Kanaya, 1961, p. 503, pl. 1, figs. 26-32; Denticulopsis seminae (Simonsen and Kanaya) Simonsen, 1979, p. 65.

Nitzschia cylindrica (Grunow) Hasle, 1965, pl. 12, figs. 6-12, pl. 14, figs. 110 , pl. 17, figs. 2-4; Sancetta, 1982, pl. 3, figs. 6, 7 .

Nitzschia grunowii Hasle, 1965, pl. 1, figs. 15-19, pl. 2, figs. 6-9, pl. 3, figs. 1, 2, pl. 16, figs. 1, 2; Sancetta, 1982, pl. 3, figs. 8-10. 
Nitzschia panduriformis Gregory, 1857, p. 529, fig. 57; Fenner, 1978, p. 525, pl. 32, figs. 27-29; Baldauf, 1985, pl. 5, fig. 8 .

Nitzschia riedelia Schrader, 1974, pl. 1, figs. 14a, b, 19.

Paralia sulcata (Ehr.) Cleve. Hustedt, 1930, fig. 119; Sancetta, 1982, pl. 3, figs. 13-15.

Porosira glacialis (Grunow) Jørgensen, 1905; Schrader and Fenner, 1976, pl. 16, figs. 1-4; pl. 197, fig. 1 .

Proboscia alata Sundström, 1986, pp. 99-102, pl. 36, figs. 258-266; Synonym: Rhizosolenia alata Brightwell, 1858, p. 95, pl. 5, figs. 8, 8a.

Proboscia curvirostris Jordan and Priddle, 1991, p. 57; Synonym: Rhizosolenia curvirostris Jousé, 1959, p. 48, pl. 2, fig. 17; Akiba and Yanagisawa, 1986, p. 497, pl. 42, figs. 1, 2; pl. 45, figs. 1-6.

Pseudoeunotia doliolus (Wallich) Grunow in Van Heurck, 1881, pl. 35, fig. 22; Baldauf, 1985, pl. 5, figs. 5-7.

Rhizosolenia hebetata forma hebetata Sundström, 1986, p. 47, 48, pl. 4, figs. $18 \mathrm{a}, \mathrm{b} ;$ pl. 17, figs. 112,113 .

Rhizosolenia hebetata forma semispina (Hensen) Gran, 1904, p. 524, pl. 17; Sundström, 1986, p. 48-52, pl. 4, figs. 19, 20; pl. 17, figs. 117, 118 .

Rhizosolenia styliformis Brightwell, 1858, p. 95, pl. 5, figs. 5a, b, d; Baldauf, 1987, pl. 6, fig. 7.

Stephanopyxis turris (Greville and Arnott) Ralfs in Pritchard, 1861, p. 826, pl. 5, fig. 74; Schrader and Fenner, 1976, pl. 30, figs. 1-10, 14; pl. 37, figs. $17-19$.
Thalassionema nitzschioides (Grunow) Van Heurck, 1896, p. 319, fig. 75; Schrader and Fenner, 1976, pl. 5, fig. 8.

Thalassiosira anguste-lineata (A. Schmidt) Fryxell and Hasle, 1977, p. 73, figs. 22-34.

Thalassiosira decipiens (Grunow) Jørgensen, 1905; Hustedt, 1930, pp. 322323, fig. 158; Schrader and Fenner, 1976, pl. 17, fig. 9.

Thalassiosira gravida Cleve, 1896, p. 12, pl. 2, figs. 14-16; Hustedt, 1928, p. 325, fig. 161; Schrader and Fenner, 1976, pl. 16, figs. 5, 6; pl. 17, fig. 2.

Thalassiosira hyalina (Grunow) Gran. Hustedt, 1930, fig. 159; Hasle and Heimdal, 1968, fig. 22; Koizumi, 1986, pl. 4, fig. 11.

Thalassiosira nidulus (Tempére and Brun) Jousé, 1961, p. 63; Schrader and Fenner, 1976, pl. 17, figs. 13, 16.

Thalassiosira nordenskioeldii Cleve, 1873, p. 7, pl. 1, fig. 11; Hustedt, 1928 , p. 321, fig. 157; Sancetta, 1982, p. 242, pl. 5, figs. 8-9.

Thalassiosira oestrupii (Ostenfeld) Proshkina-Lavrenko, 1949; Hasle, 1960, p. 8, pl. 1, figs. 5-7; Akiba, 1986, pl. 14, figs. 1-6.

Thalassiosira plicata Schrader, 1974, p. 917, pl. 3, figs. 1, 2, 4-9.

Thalassiosira trifulta Fryxell in Fryxell and Hasle, 1979, p. 16, pls. 1-5, figs. 1-24; Sancetta, 1982, p. 244, pl. 5, figs. 10-12.

Thalassiosira zabelinae Jousé, 1961, p. 66, pl. 2, figs. 1-7; Akiba, 1986, pl. 8, fig. 11.

Thalassiothrix longissima Cleve and Grunow, 1880, Hustedt, 1932, p. 247, fig. 726; Hasle and Semina, 1987, figs. 1-25.

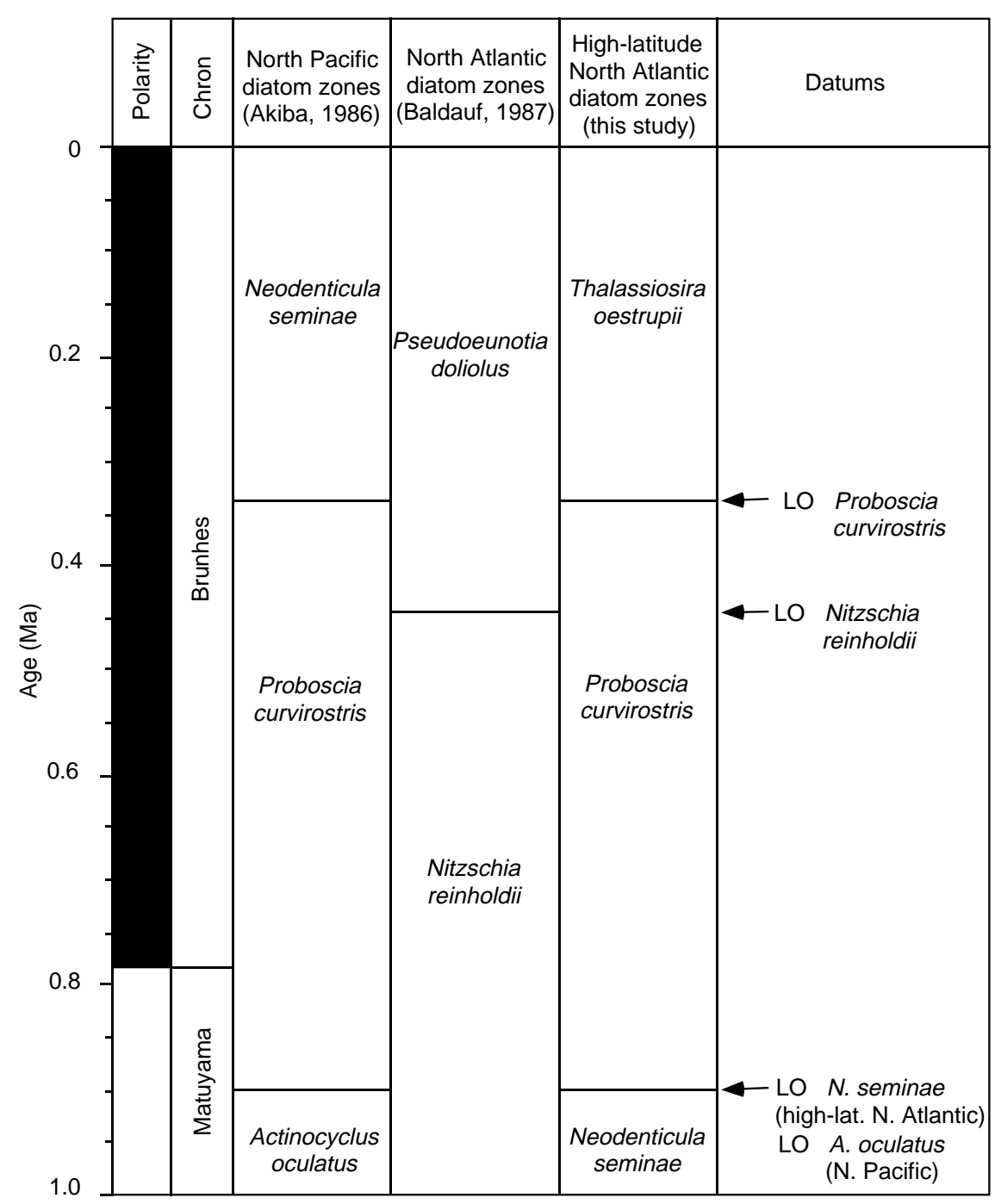

Figure 5. Correlation of various Pleistocene diatom zones and the first-order datums. $\mathrm{LO}=$ last occurrence. 


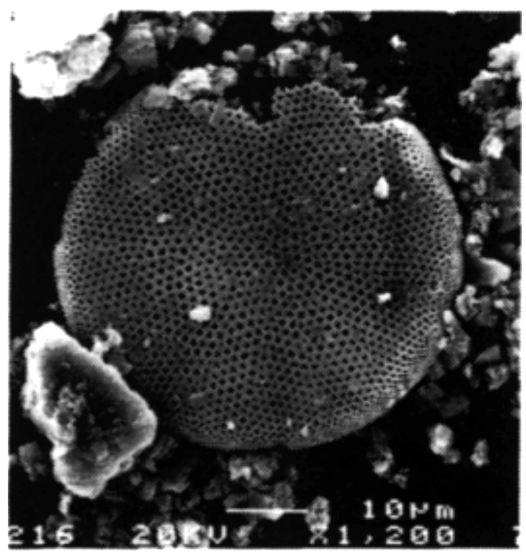

1

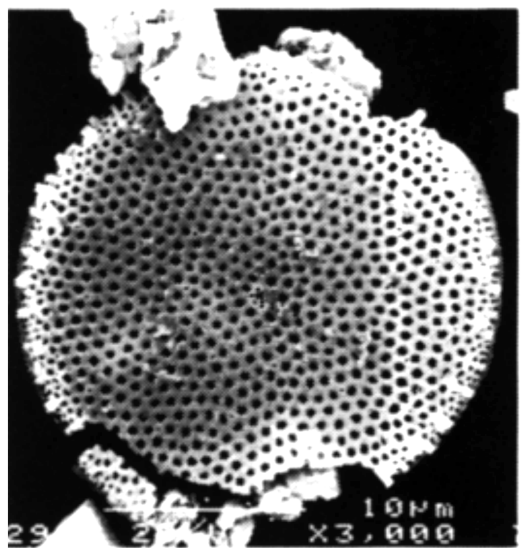

4

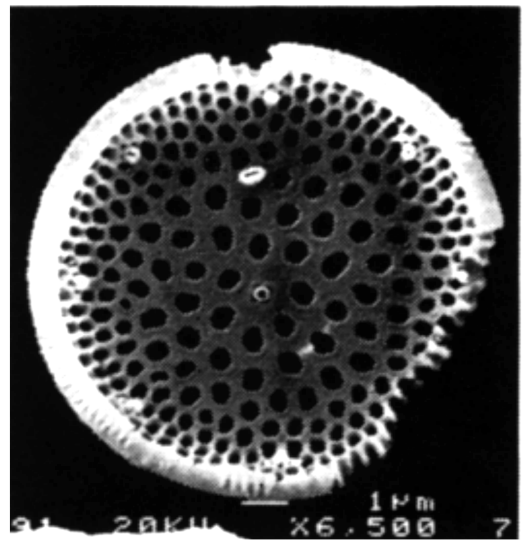

7

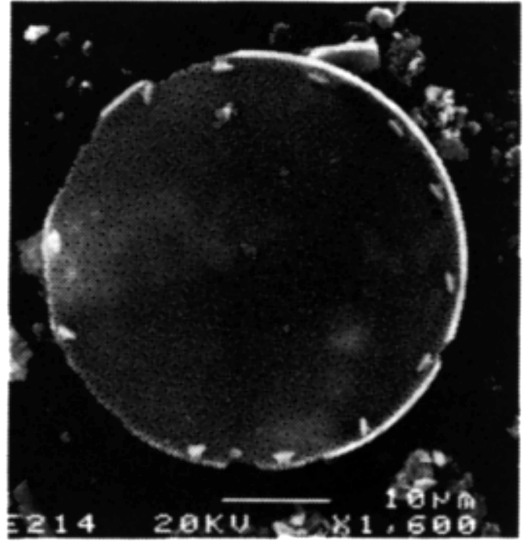

2

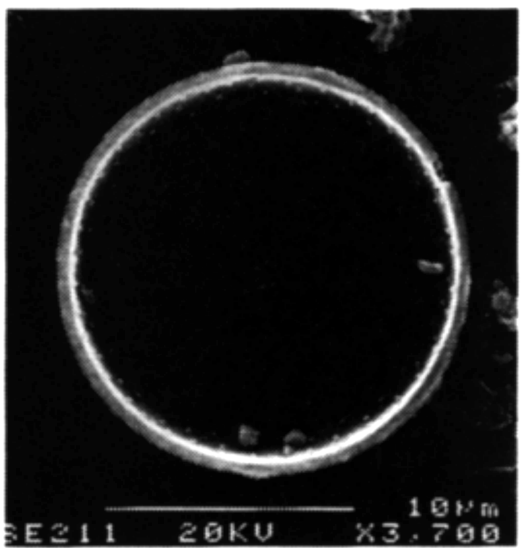

5

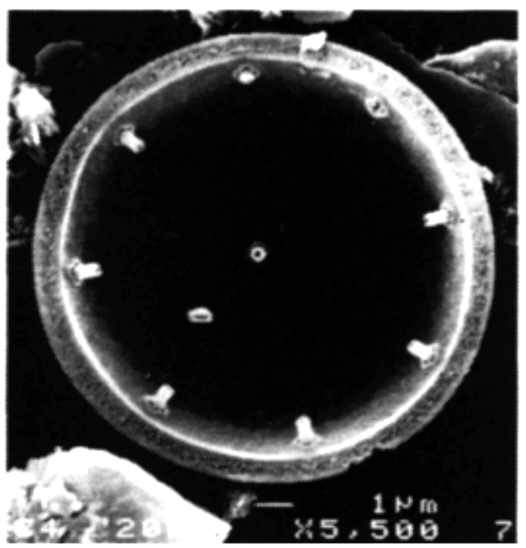

8

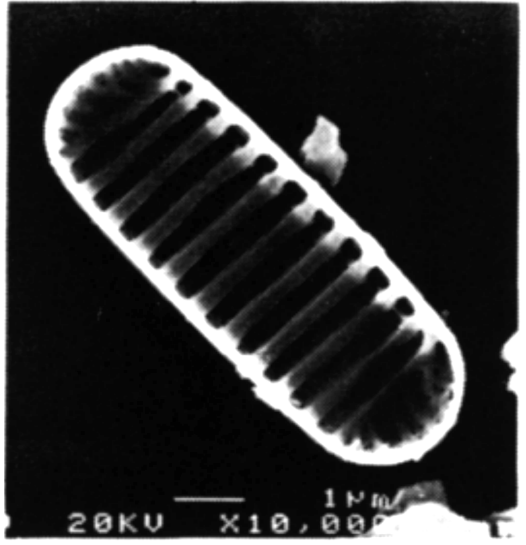

3

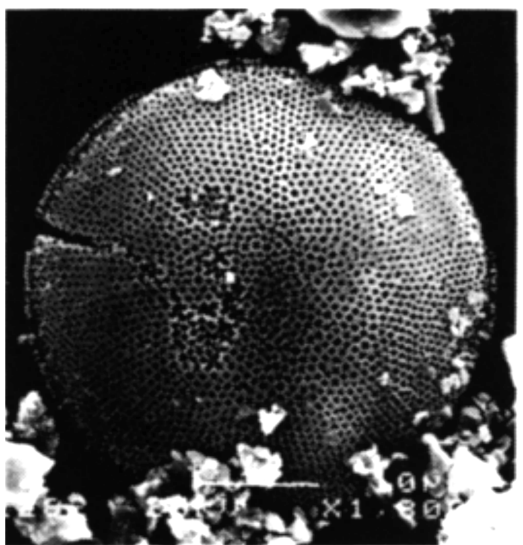

6

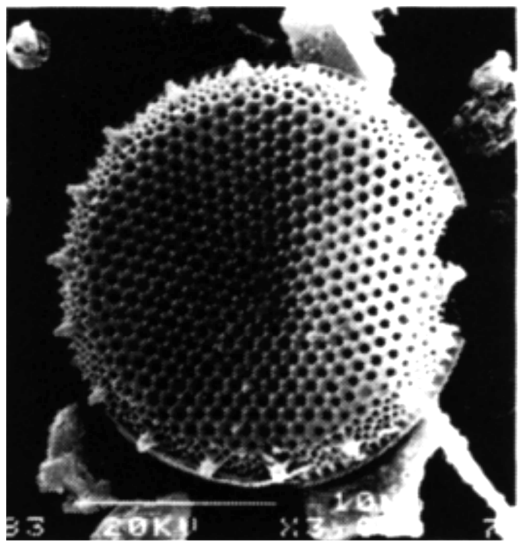

9

Plate 1. Scale bar $=10 \mu \mathrm{m}$, unless otherwise indicated. 1. Actinocyclus curvatulus Janisch, SEM, external view of valve face with arrow pointing at the pseudonodulus, Sample 152-919A-5H-7, 35-36 cm. 2. Actinocyclus curvatulus Janisch, SEM, internal view of valve face with labiate processes along the margin, Sample 152-919A-5H-7, 35-36 cm. 3. Nitzschia cylindrica (Grunow) Hasle, SEM, internal view of valve face, Sample 152919A-7H-7, 40-41 cm. Scale bar $=1 \mu \mathrm{m}$. 4. Thalassiosira gravida Cleve vegetative cell, SEM, external view of valve face with more than two rows of marginal spines, cluster of central pores and spines scattered all over the valve face, Sample 152-919B-8H-5, 20-21 cm. 5. Thalassiosira gravida Cleve vegetative cell, SEM, internal view of valve face with, in addition to the above features, a marginal labiate process at three o'clock, Sample 152-919A-5H-7, 35-36 cm. 6. Thalassiosira gravida Cleve resting spore, SEM, external view of valve face, Sample 152-919A-7H-7, 40$41 \mathrm{~cm}$. 7. Thalassiosira oestrupii (Ostenfeld) Proshkina-Lavrenko, internal view of valve face with a row of marginal spines, a central process and a labiate process halfway between the center and the margin, Sample 152-919B-8H-5, 20-21 cm. Scale bar $=1 \mu \mathrm{m}$. 8. Thalassiosira oestrupii (Ostenfeld) Proshkina-Lavrenko, internal view of valve face, Sample 152-919A-7H-7, 40-41 cm. Scale bar $=1 \mu \mathrm{m}$. 9. Thalassiosira angustelineata (A. Schmidt) Fryxell and Hasle, SEM, external view of valve face, Sample 152-919A-7H-7, 40-41 cm. 


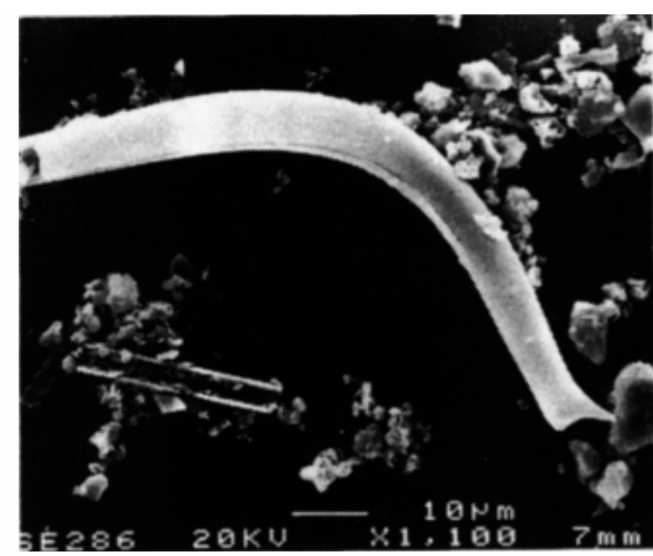

1

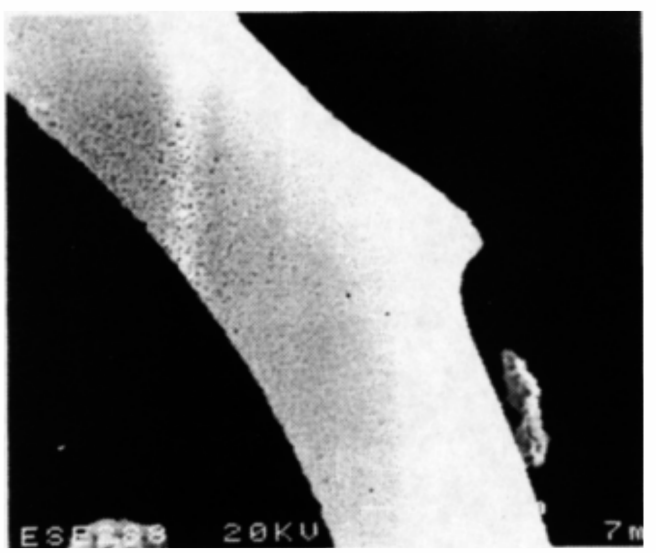

3

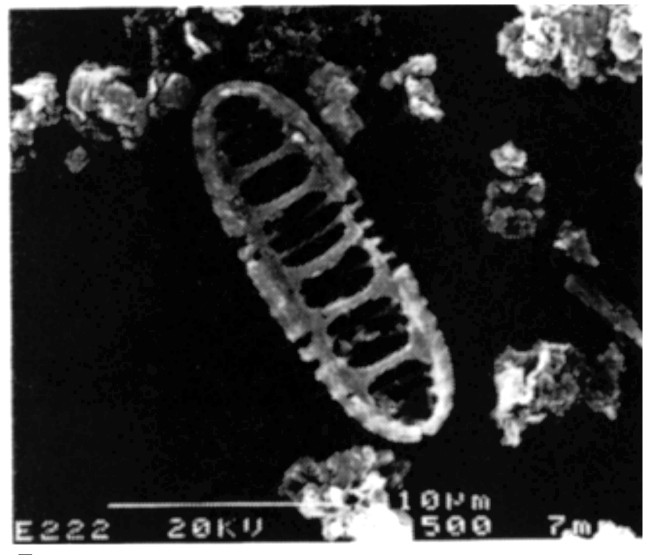

5

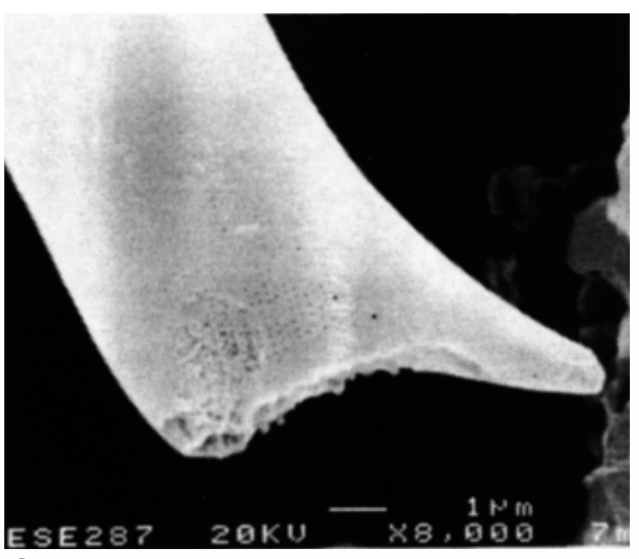

2

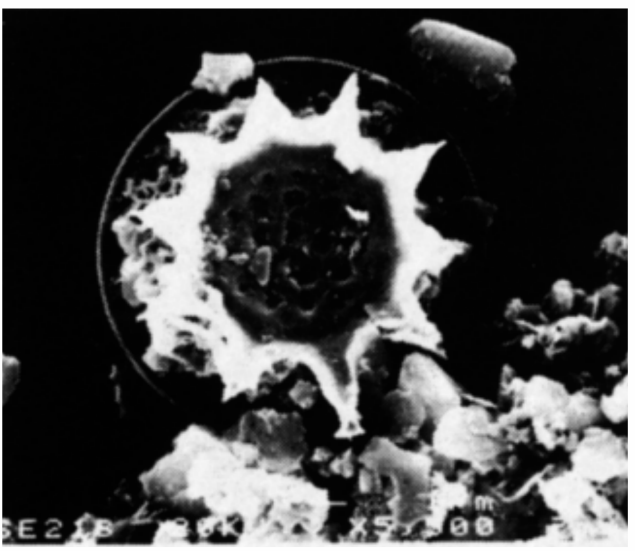

4

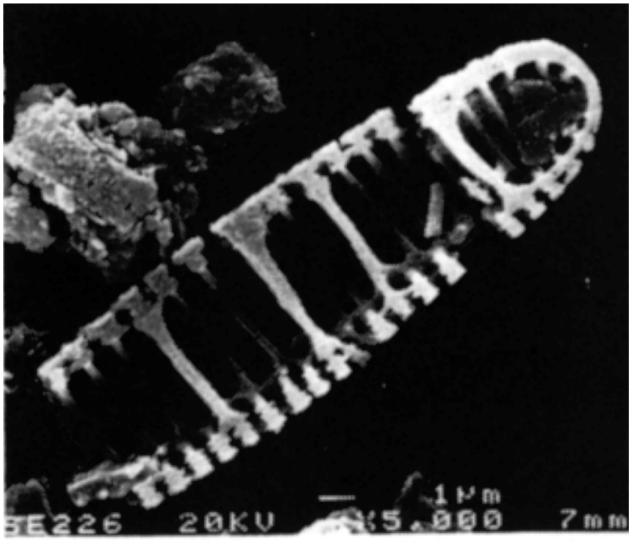

6

Plate 2. Scale bar $=10 \mu \mathrm{m}$, unless otherwise indicated. 1. Proboscia curvirostris Jordan and Priddle, Sample 152919A-7H-7, 40-41 cm. 2. Enlarged view of Figure 1, showing dentate end. Scale bar $=1 \mu \mathrm{m}$. 3. Proboscia curvirostris Jordan and Priddle. Detail showing a triangular spine, Sample 152-919A-7H-7, 40-41 cm. Scale bar $=1 \mu \mathrm{m}$; magnification is 5,500×. 4. Thalassiosira nidulus (Tempére and Brun) Jousé, Sample 152-919A-5H-7, 35-36 cm. Scale bar = $1 \mu \mathrm{m}$. 5. Neodenticula seminae (Simonsen and Kanaya) Akiba and Yanagisawa, internal view of valve face, Sample 152-919B-8H-1, 95-96 cm. 6. Neodenticula seminae (Simonsen and Kanaya) Akiba and Yanagisawa, internal view of valve face, Sample 152-919B-8H-1, 95-96 cm. Scale bar $=1 \mu \mathrm{m}$. 